\title{
Morphology and topographic anatomy of the spinal cord of the red-footed tortoise (Geochelone carbonaria Spix, 1824) ${ }^{1}$
}

\author{
Rafael C. Carvalho ${ }^{2 *}$, Alana L. Sousa ${ }^{3}$, Sâmia C.R. Oliveira ${ }^{4}$, Ana C.B.C. F. Pinto ${ }^{5}$, \\ José H. Fontenelle ${ }^{6}$ and Silvia R.G. Cortopassi ${ }^{5}$
}

\begin{abstract}
Carvalho R.C., Sousa A.L., Oliveira S.C.R., Pinto A.C.B.F., Fontenelle J.H. \& Cortopassi S.R.G. 2011. Morphology and topographic anatomy of the spinal cord of the red-footed tortoise (Geochelone carbonaria Spix, 1824). Pesquisa Veterinária Brasileira 31(Supl.1): 47-52. Universidade Federal do Maranhão, BR $222 \mathrm{Km} 4$ s/n, Chapadinha, MA 65500-000, Brazil.E-mail: rafaelcarvalho@ufma.br

The aim of this study was to describe the topography of the spinal cord of the red-footed tortoise to establish a morphological basis for applied research in anesthesiology and morphology. Six tortoises from the state of Maranhão (Brazil) that had died of natural causes were used. The common carotid artery was used to perfuse the arterial system with saline solution (heated to $37^{\circ} \mathrm{C}$ ) and to fix the material with a $20 \%$ formaldehyde solution. The specimens were then placed in a modified decalcifying solution for 72 hours to allow dorsal opening of the carapace with a chisel and an orthopedic hammer. Dissection of the dorsal musculature and sectioning of the vertebral arches were performed to access the spinal cord. The results revealed the spinal cord of G. carbonaria to be an elongated, whitish mass that reached the articulation between the penultimate and last caudal vertebrae. The cervical intumescence (Intumescentia cervicalis) was located between vertebral segments C5 and T1, whereas the lumbosacral intumescence (Intumescentia lumbalis) was located between $\mathrm{T} 6$ and Ca1.
\end{abstract}

INDEX TERMS: Morphology, spinal cord, Geochelone carbonaria red-footed tortoise, topographic anatomy.

RESUMO.- [Morfologia e anatomia topográfica da medula espinal de jabuti das "patas vermelhas" (Geochelone carbonaria Spix, 1824).] Objetivou-se com este estudo descrever a topografia da medula espinhal do jabuti de "patas vermelhas" no intuito de estabelecer bases morfológicas para a investigação aplicada em morfologia, anestesiologia e cirurgia animal. Foram utilizados seis animais

\footnotetext{
${ }^{1}$ Received on March 28, 2011.

Accepted for publication on November 22, 2011.

${ }^{2}$ Centro de Ciências Agrárias e Ambientais, Universidade Federal do Maranhão, BR 222 Km 4, Chapadinha, MA 65500-000, Brazil. *Corresponding author: rafaelcarvalho@ufma.br

${ }^{3}$ Departamento das Clínicas Veterinárias, Universidade Estadual do Maranhão (UFMA), Cidade Universitária Paulo VI, São Luís, MA, 65055-970, Brazil.

${ }^{4}$ Instituto Federal do Maranhão (IFMA), Av. Luís Firmino de Sousa 3907, Mutirão, Timon, MA 65635-468, Brazil.

${ }^{5}$ Departamento de Cirurgia, Faculdade de Medicina Veterinária e Zootecnia (FMVZ), Universidade de São Paulo (USP), Av. Prof. Dr. Orlando Marques de Paiva 87, Cidade Universitária, São Paulo, SP 05508-900, Brazil.

${ }^{6}$ Orquidário Municipal de Santos, Praça Washington s/n, José Menino, Santos, SP 11065-600, Brazil.
}

adultos, provenientes do Estado de Maranhão (Brasil), os quais haviam ido a óbito por causas naturais. A artéria carótida comum foi canulada e utilizada para perfusão do sistema arterial com solução salina (aquecida a $37^{\circ} \mathrm{C}$ ) e para fixação do material com uma solução de formol a $20 \%$. Os animais foram então colocados em uma solução descalcificadora modificada por 72 horas, o que facilitou a abertura dorsal da carapaça com um cizel e um martelo ortopédico. Em seguida, foi realizada a dissecação da musculatura dorsal e secção dos arcos vertebrais para acesso a medula espinal. Os resultados revelaram a medula espinhal de Geochelone carbonaria como uma massa alongada, esbranquiçada, que se estende até a articulação entre penúltima e última vértebra caudal. A intumescência cervical (Intumescentia cervicalis) foi localizada entre os segmentos vertebrais de C5 e T1, enquanto que a intumescência lombossacral (Intumescentia lumbalis) foi localizada entre os segmentos vertebrais de T6 e Ca1.

TERMOS DE INDEXAÇÃO: Morfologia, medula espinal, Geochelone carbonária, anatomia topográfica. 


\section{INTRODUCTION}

Tortoises are land reptiles that originate from hot, dry regions and are found in the tropics of South America: in the Guyanas, Venezuela, Ecuador, Brazil, Paraguay and several islands in the Caribbean (Pritchard 1979, Troiano 1991, Villa 1994, Romer 1997, Carvalho et al. 2003). These animals live in a range of environments, from the rainforest to the savannah and semi-arid regions. In Brazil, they are frequently located in the northeastern, southeastern and southern regions of the country, where they vary in size and coloration. Two species merit special attention: Geochelone carbonaria, the red-footed tortoise, and Geochelone denticulata, the yellow-footed tortoise. These animals are protected by the Fauna Law and monitored by the Brazilian Environmental Agency (Ibama - Instituto Brasileiro de Meio Ambiente e dos Recursos Naturais Renováveis). As for all wild animals, special authorization is required to raise these tortoises in captivity (Faria 2000, Carvalho et al. 2003).

Tortoises are often kept as pets in Brazil, where they may be raised in captivity and subjected to inadequate management, mainly because of a lack of knowledge on the part of those who maintain them. Inadequate conditions can lead to health problems, such as vitamin deficiency, respiratory illness, shell deformity, abscesses, anorexia, pseudo-hibernation, parasitism and metabolic diseases. There may also be complications such as gastrointestinal obstruction and rectal, vaginal and penile prolapse. These conditions have become common in veterinary clinics and usually require surgical repair (Messonier 1996).

The specialized literature on reptiles offers little specificity in morphological studies on the species that make up this order. Regarding the nervous system, studies have not been carried out in a clear, specific manner for each species. There are no studies in the literature regarding the anatomy of the central nervous system of Geochelone carbonaria. Anatomic descriptions of the nervous systems of wild animals are of fundamental importance to have an accurate knowledge of their morphologies, whether this knowledge is used for evolutionary descriptions or a basis for clinical-surgical and behavioral approaches. Morphological knowledge of the interactions between the medulla and spinal column (spinal cord topography) is important to veterinarians and biologists for comparison with other wild and domesticated species, especially with regard to anesthetic methods, including spinal anesthesia (Fontenelle et al. 2000, Silva et al. 2002).

Despite this tortoise's wide geographic distribution, there is little information on the nervous system morphology of $G$. carbonaria, although some biological descriptions are found in specialized literature. Thus, the aim of the present study was to describe the spinal cord topography in $G$. carbonaria to obtain basic morphological information for use in anesthesiology and comparative anatomical studies.

\section{MATERIALS AND METHODS}

Six adult red-footed tortoises Geochelone carbonaria (3 males and 3 females) of different ages were studied. Tree males and tree females were donated by the Center for the Study and Preservation of Wildlife of the Universidade Estadual do Maranhão (Brazil); one male and one female were donated by the Zoological Park Foundation of São Paulo (Brazil). All specimens had died of natural causes. After death these animals were frozen to ensure that their spinal cords had not degraded. It is noteworthy that all the procedures such as handling, storage and dissection of animals were the same for all animals. The present study was carried out in compliance with the guidelines of the Bioethics Committee of the School of Veterinary Medicine, Universidade de São Paulo and authorized by the Brazilian Environmental Agency (Ibama License no 02027.021070/03-80).

The weight of the specimens ranged from $3.0 \mathrm{~kg}$ to $5.5 \mathrm{~kg}$ (means of $3.5 \mathrm{~kg}$ for females and $4.5 \mathrm{~kg}$ for males). The carotid artery was accessed for lavage of the arterial circuit with saline solution heated to $37^{\circ} \mathrm{C}$ and subsequent fixation with a $20 \%$ formaldehyde solution. During the fixation process, the specimens were held in the dorsal decubitus position, with the neck, limbs and tail extended. To allow dorsal access to the spinal column and cord, the pieces were decalcified by immersion in a solution of equal parts chlorhydric acid, acetic acid, alcohol and water for 36 to 48 hours to make the carapace flexible and to facilitate access to the spinal cord. A chisel and orthopedic hammer were used for the dorsal opening of the carapace, which was removed from the boney and corneal plates, respecting the rectangular band of the carapace that contains the spinal cord canal. Dissection of the dorsal musculature, nerves, ganglia and structures adjacent to the spinal column was performed until the vertebral arches were exposed; these arches were sectioned to expose the spinal cord. This step was carried out with due care to preserve the nerve structures as well as the topographic relations and vertebral-cord syntopy. Dissection of the dura mater and exposure of the rootlets, nerve roots and nerves formed by these roots were carried out with the aid of a magnifying glass.

The anatomic structures were recorded and photographed. Cuts of spinal cord segments from one male and one female were taken for histological study under a light microscope, following routine procedures of the Histology Laboratory of the School of Veterinary Medicine, Universidade de São Paulo. The spinal cord was sectioned at five points: cervical intumescence (Intumescentia cervicalis), lumbosacral intumescence (Intumescentia lumbalis), and the cranial, mid and caudal thirds of the tail. These segments were fixed in a $10 \%$ formaldehyde solution, embedded in paraffin, sectioned (5-mm thickness) and stained with Hematoxylin-Eosin. The slides were analyzed and photographed.

\section{RESULTS}

The spinal cord of Geochelone carbonaria is an elongated, cylindrical whitish mass, slightly flattened dorso-ventrally, that fills the vertebral canal. These morphological characteristics were common in all animals studied. It is continuous at the cranial end with the medulla oblongata and $4^{\text {th }}$ ventricle as well as the caudal vertebrae, ending between the penultimate and last caudal vertebrae. Histologically, the terminal segment is formed by bodies of neurons and neuroglial cells, revealing the continuity of the spinal cord. No equine tail or terminal filament originating from the lining layers was observed (Fig.1A). The spinal cord is enveloped by three delicate, concentric meninges: the pia mater, the arachnoid and the dura mater. The innermost lining (the pia mater) is a thin, vascular membrane closely attached to the surface of the spinal cord and its nerve roots. The translucent arachnoid is 
found between the dura mater and the pia mater. It lines the spinal cord like a loose sack, joining the dura mater to the pia mater. The outermost lining (the dura mater) is thick and fibrous. It covers the spinal cord loosely and is in contact with the arachnoid. The dura mater is separated from the periosteum of the vertebral canal by the epidural, peridural or extradural space, which contains a small amount of adipose tissue and the vessels that go on to constitute the vertebral plexuses. Its diameter is not uniform; two dilatations (the cervical and lumbosacral intumescences) stem from the nerve roots that give rise to the nerves of the brachial and lumbosacral plexuses, which innervate the thoracic and pelvic limbs, respectively (Fig.1C,D). The cervical intumescence (Intumescentia cervicalis) is formed by spinal cord segments $C_{5}$ to $T_{1}$, and the lumbosacral intumescence is formed by segments $\mathrm{T}_{6}$ to $\mathrm{Ca}_{1}$. These structures are produced by most of the neurons in the gray matter of the spinal cord.
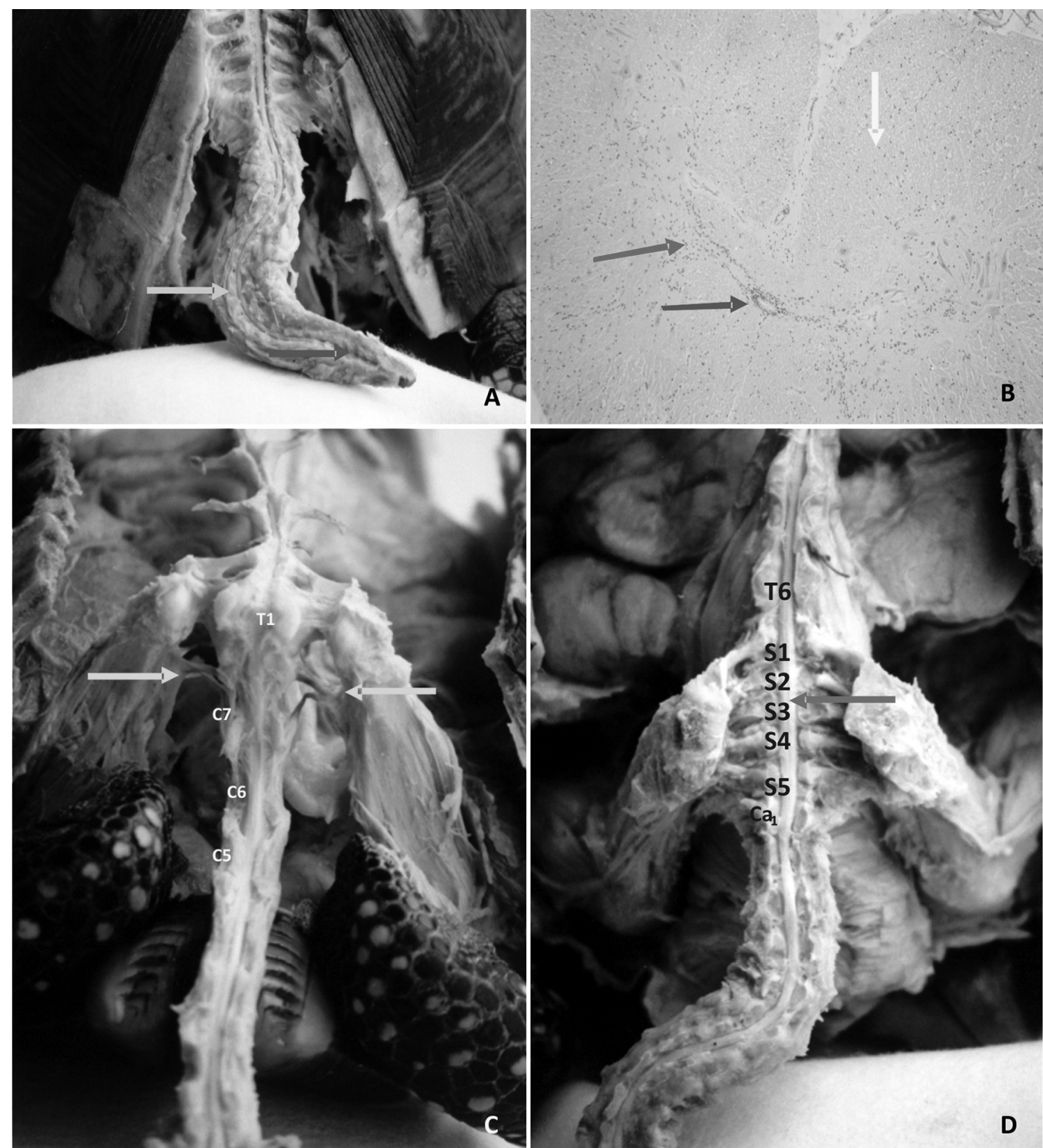

Fig.1. Geochelone carbonaria. (A) Dorsal view: termination of the spinal cord at the last articulation of the tail (between the penultimate and last caudal vertebrae), highlighting the spinal column $(\rightarrow$ ) and the vertebral canal at the end of the tail $(\rightarrow)$. (B) Histological slice of spinal cord from $G$. carbonaria; cross-section of the cervical intumescence, with grey matter in the central area $(\rightarrow)$ and white matter in the peripheral area $(\rightarrow)$; note the center of the " $\mathrm{H}$ " of the spinal cord, part of its "arms" and the central canal $(\rightarrow)$; HE Hematoxylin Eosin staining, 20x. (C) Dorsal view: cervico-dorsal intumescence (C5-T1 spinal cord segments) and constituent nerves of the brachial plexus $(\rightarrow)$. (D) Dorsal view: lumbosacral intumescence (T6-Ca1 spinal cord segments); pattern in males, highlighting the dorsal median groove $(\rightarrow)$. 
The spinal cord is contained in the spinal canal, which is made of up seven cervical vertebrae, six thoracic vertebrae, five sacral vertebrae and 23 to 29 caudal vertebrae. The spinal nerves emerge through intervertebral foramens. Branch $\mathrm{C}_{1}$ emerges between the first cervical vertebra and the occipital bone; branches $\mathrm{C}_{2}$ to $\mathrm{C}_{7}$ emerge above their corresponding vertebrae; branch $\mathrm{C}_{8}$ emerges between the seventh cervical vertebra and first thoracic vertebra. All thoracic, sacral and caudal nerves emerge caudo-laterally to their corresponding vertebrae. Along its length, the spinal column has an orderly, segmented pattern of 42 to 48 pairs of spinal nerves ( 8 cervical, 6 thoracic and 5 sacral, with 27 to 29 caudal nerves in males and 23 to 25 in females). This segmented pattern is reflected in the internal organization. Each segment corresponds to four roots (1 ventral and 1 dorsal on both the left and right halves). Each of the 48 pairs of spinal nerves has one ventral and one dorsal root; each root is made up of three to eight rootlets, which are formed from bundles of nerve fibers. The ganglion in each dorsal root of the spinal cord is located near the junction with the ventral root; each is an intumescence that contains the bodies of neurons that go on to make up the ganglia of the sympathetic chain. Each spinal nerve is divided to form the primary dorsal and ventral branches. The primary dorsal branch innervates the musculature of the body cavity and areas associated with the carapace. The primary dorsal branch is generally larger than the dorsal branch and is involved in the formation of the nerves of the brachial and lombosacral plexuses at the level of the intumescences.

Histologically, the gray matter occupies the central position and is shaped like a butterfly or an $\mathrm{H}$, although its "arms" are not well circumscribed (Fig.1B). The white matter is made up of two symmetrical portions that are united on the median line. Tables 1 and 2 show the locations of the cervical and lombosacral intumescences as well as the distribution (frequency) of the nerve roots that make up the brachial and lombosacral plexuses in the analyzed sample.

Table 1. Origin and location of cervical intumescence (Intumescentia cervicalis) and distribution of brachial plexus in Geochelone carbonaria. Sao Paulo/SP, 2004

\begin{tabular}{lcc}
\hline \multicolumn{1}{c}{ Origin (Nerve roots) } & Location & Distribution (\%) \\
\hline $\mathrm{C}_{5} \mathrm{C}_{6} \mathrm{C}_{7} \mathrm{C}_{8}$ & $\mathrm{C}_{4}-\mathrm{C}_{7}$ & 33.33 \\
$\mathrm{C}_{5} \mathrm{C}_{6} \mathrm{C}_{7} \mathrm{C}_{8} \mathrm{~T}_{1}$ & $\mathrm{C}_{4}-\mathrm{T}_{1}$ & 33.33 \\
$\mathrm{C}_{6} \mathrm{C}_{7} \mathrm{C}_{8} \mathrm{~T}_{1}$ & $\mathrm{C}_{6}-\mathrm{T}_{1}$ & 33.33
\end{tabular}

Table 2. Origin and location of the lumbosacral intumescence (Intumescentia lumbalis) and distribution of the lumbosacral plexus in Geochelone carbonaria. Sao Paulo/SP, 2004

\begin{tabular}{lll}
\hline Origin (Nerve roots) & Location & Distribution (\%) \\
\hline $\mathrm{D}_{6} \mathrm{~S}_{1} \mathrm{~S}_{2} \mathrm{~S}_{3} \mathrm{~S}_{4} \mathrm{~S}_{5}$ & $\mathrm{D}_{6}-\mathrm{S}_{5}$ & 33.33 \\
$\mathrm{D}_{6} \mathrm{~S}_{1} \mathrm{~S}_{2} \mathrm{~S}_{3} \mathrm{~S}_{4} \mathrm{~S}_{5} \mathrm{Ca}_{1}$ & $\mathrm{D}_{6}-\mathrm{Ca}_{1}$ & 33.33 \\
$\mathrm{~S}_{1} \mathrm{~S}_{2} \mathrm{~S}_{3} \mathrm{~S}_{4} \mathrm{~S}_{5}$ & $\mathrm{~S}_{1}-\mathrm{S}_{5}$ & 33.33
\end{tabular}

\section{DISCUSSION}

Studies on the anatomy, physiology and pathology of tortoises are rare and offer little specificity. Research on the species studied here (Geochelone carbonaria) is still in its early stages, with few studies available to date. With regard to the nervous system of this species, the present study is preliminary, as there is no reference to this subject in the specialized literature.

The nervous system in reptiles is made up of a brain and spinal cord. The brain is proportionately smaller than that of mammals and does not rest completely in the cranial cavity. It is divided into three main parts (the forebrain, midbrain and hindbrain), which are attached to one another by one or two pairs of cranial nerves. A large portion of the forebrain is composed of the brain hemispheres, with two cavities called lateral ventricles. Each hemisphere is broader in its anterior portion, forming the olfactory bulb; structures such as the pineal gland and hypothalamus also make up part of this region of the brain. The midbrain is the control center and performs the functions of the mammalian cortex. The hindbrain is made up of a small cerebellum (without lobules) and the medulla oblongata, which is important to the regulation and control of vagus nerve activity (Anthony 1970, Guibé 1970, Kuhlenbeck 1975, Mader 1996).

The spinal cord in $G$. carbonaria originates caudal to the brain and is contained within the vertebral canal. Externally, it has extensive areas of white matter rich in fibers that carry the impulses from the brain to the body and vice versa. It has a relatively large diameter from the brain to the sacral region; from this region downward, a relatively small number of cells carry local reflexes. Its diameter is not uniform along its length. There are dilatations in both the cervical and lumbar regions because the greater number of neurons destined to innervate the limb musculature creates a greater expansion of the gray matter in the spinal cord (Romer 1997, Romero 2000). In agreement with Anthony (1970), Kuhlenbeck (1975), Troiano (1991) and Mader (1996), the spinal cord extends to the tip of the tail, and there is an absence of structures such as the terminal filament and equine tail. Two classic thickenings (cervical and lumbosacral) are formed, and the plexuses that emerge from them go on to innervate the thoracic and pelvic limbs.

Anthony (1970), Kuhlenbeck (1975), Troiano (1991), Mader (1996) and Romer (1997) describe the spinal cord of reptiles as contained within the vertebral canal, originating caudal to the brain and extending to the tip of the tail. The nerve plexuses emerge from two thicker portions of the spinal cord and innervate the musculature of the thoracic and pelvic limbs, as described for $G$. carbonaria in the present study; however, the reports from previous authors are general, with little specificity. There is no reference to the location of the intumescences, and there is no detailed anatomical description of the structures related to the spinal column. Another controversial aspect of these studies is the nomenclature adopted. This nomenclature is generic and dissimilar across descriptions and thus is non-specific, as there is evident differentiation among the orders that make up the class Reptilia. Terms employed for tortoises may not be valid for crocodiles, lizards or snakes, as these animals have distinct characteristics.

In a study on the nervous system of reptiles, Hildebrand (1995) provides a more detailed description of the anatomy 
of the spinal cord. These structures are cited by Gil (1998) in a neurological study on cats and dogs and are also observed in G. carbonaria [a finding that may be explained by Hildebrand's statement (1995) regarding the evolutionarily conserved nature of the central nervous system]. Thus, there is evidence of similarity between these tortoises and domesticated mammals: a dorsal median groove and ventral median fissure divide the spinal cord into a left and right half. Kuhlenbeck (1975) and Hildebrand (1995) add that, microscopically, the gray matter is internal and irregular in shape, resembling the letter " $\mathrm{H}$ ", with the upper arms of the $\mathrm{H}$ forming the dorsal gray columns (or horns) and the lower arms (shorter and broader) forming the ventral gray columns (or horns). These same characteristics are clearly seen in the spinal column of the red-footed tortoise.

The spinal column of $G$. carbonaria is enveloped in three layers of meninges: the dura mater (outermost layer), the arachnoid (middle layer) and the pia mater (innermost layer). This finding is in agreement with studies by Dellmann \& McClure (1986), Molenaar (1997) and Gil (1998) and a study by Baumel (1986) on birds; however, in a description of the central nervous system of reptiles, Mader (1996) observes differences from G. carbonaria: according to those findings, the spinal cord in reptiles is enveloped in two meninges (the dura mater and pia-arachnoid) rather than three. The dura mater is the outermost layer; it is in contact with the wall of the spinal cord, but the author does not describe these membranes. In contrast, Kuhlenbeck (1975) and Hildebrand (1995) report that reptiles have three surrounding membranes, as in mammals and birds.

In $G$. carbonaria, the intumescences varied significantly in their distribution, with the cervical intumescence (Intumescentia cervicalis) varying between $\mathrm{C}_{4}$ and $\mathrm{T}_{1}$ and the lumbosacral intumescence (Intumescentia lumbalis) varying between $\mathrm{T}_{6}$ and $\mathrm{Ca}_{1}$. Certain aspects should be discussed with regard to the distribution. The apparent origins of the roots that form the cervical intumescence had the following frequencies: $33.33 \% \mathrm{C}_{4}-\mathrm{C}_{7} 33.33 \% \mathrm{C}_{4}-\mathrm{T}_{1}$ and $33.33 \%$ $\mathrm{C}_{6}-\mathrm{T}_{1}$ (Table 1). It is thus evident that there is no characteristic distribution pattern in this species, as the distribution is the same for all three groups. It should be stressed that the $\mathrm{C}_{6}-\mathrm{T}_{1}$ distribution is more caudal than the other two and that this distribution is found in the females in this sample set. Although the distribution in the females is the same as in the males, these results do not necessarily represent the origin pattern and distribution of roots for females because only a small number of animals were analyzed. The observed frequency may be the result of chance or physiological factors such as age, muscle activity or other factors that affect spinal cord development and that may not be known because of the origins of these animals. According to De Lahunta (1983), the spinal cord in the regions of the members broadens because of the volume and muscle activity of the innervated tissue, which suggests that this pattern may hold for both males and females.

As in birds (Baumel 1993), the lumbosacral plexus in G. carbonaria is a network of nerves that serve the pelvic limbs. This structure is made up of two plexuses (lumbar and sacral) united by a shared root. The roots of these ple- xuses stem from the lumbosacral intumescence of the spinal cord, which is contained in a fusiform (spindle-shaped) segment and which expands from the synsacrum. In addition, $33.33 \%$ of the samples in the present study had a caudal plexus (coccygeum).

Regarding the distribution of the roots that form the lumbosacral intumescence, the $\mathrm{T}_{6}-\mathrm{Ca}_{1}$ variation had the following frequencies: $33.33 \% \mathrm{~S}_{1}-\mathrm{S}_{5}, 33.33 \% \mathrm{~T}_{6}-\mathrm{S}_{5}$ and $33.33 \% \mathrm{~T}_{6}-\mathrm{Ca}_{1}$ (Table 2). Thus, once again, no characteristic pattern was seen for the species, as the frequency was the same for all distributions found. The females exhibit the same distribution of the nerve roots as the males. In all the females of tortoises (33.33\%), roots forming the lumbosacral sacral plexus are found between $S_{1}$ and $S_{5}$. Unlike the structures in birds and the tortoises studied in this investigation, this distribution does not involve the lumbar or caudal plexuses. This distribution differs from the other two in a number of respects. The first is the absence of a lumbar plexus. Additionally, the first nerve that makes up this plexus is more caudal than in the other two distributions, in which the first nerve stems from $\mathrm{T}_{6}$. It is possible that this more caudal development is a consequence of spinal cord development; in the females analyzed, the first nerve in the cervical plexus is more caudal when compared with the pattern seen in the male specimens $\left(\mathrm{C}_{6}\right)$. Moreover, the segments from the caudal spinal cord are not involved in this plexus, which is restricted to the sacral segments. This observation further differentiates these findings from those reported by Baumel (1993) in birds. Baumel (1993) describes a lumbosacral plexus composed of roots that stem from the lumbar, sacral, pudendal and caudal plexuses. No pudendal plexus is found in G. carbonaria.

A second arrangement of the apparent origin of the nerves that make up the lumbosacral intumescence $\left(\mathrm{T}_{6}-\mathrm{S}_{5}\right)$, which also had a frequency of $33.33 \%$, resembles the findings of many other authors and exhibits no involvement of nerve roots from the caudal and/or pudendal plexus. This finding is similar to observations in domesticated mammals, such as cats, dogs, horses and cattle (Ghoshal 1986) and may reveal that the functional significance of the involvement of a caudal and/or pudendal plexus in this species is questionable. The absence of such structures does not cause any variation in normal locomotion, suggesting that its function can be carried out by the constituent nerves of the sacral plexus. This observation is in accord with Romer (1997); although the spinal cord extends to the tip of the tail, the innervation originating from it is relatively minor, as fewer cells are needed to carry local reflexes from the caudal region.

The third arrangement $\left(\mathrm{T}_{6}-\mathrm{Ca}_{1}\right)$, which also had a frequency of $33.33 \%$, had the broadest range, with the involvement of the lumbar, sacral and caudal plexuses. This arrangement resembles the pattern found in birds (Baumel, 1993). Thus, although G. carbonaria is a reptile and is considered less evolutionarily complex than birds, it has a well differentiated and diversified distribution, as the arrangement of the nerve origins that form the plexuses matches the pattern found in birds $\left(\mathrm{T}_{6}-\mathrm{Ca}_{1}\right)$ and mammals $\left(\mathrm{T}_{6}-\mathrm{S}_{5}\right.$ as in Baumel (1993) and Ghoshal (1986), respectively. The- 
se animals also have a species-specific distribution $\left(\mathrm{S}_{1}-\mathrm{S}_{5}\right)$, which is intermediate in relation to the other two and which does not resemble any other pattern cited in the literature consulted.

Spinal cord syntopy in the red-footed tortoise is harmonic. The results of the present study reveal that the segmentation is uniform and that the arrangement of the nerve roots and their interactions with the spinal column are symmetric. Aside from the organization of the spinal cord fibers and roots, a number of other factors may contribute to this symmetry.

From the results of the present study, the following conclusions may be drawn: the spinal cord in G. carbonaria is a whitish, elongated cylindrical mass that is slightly flattened dorso-ventrally, filling the vertebral canal until the final caudal vertebrae; there is a cervicothoracic intumescence between spinal cord segments $\mathrm{C} 5$ and $\mathrm{T} 1$ and a thoracic-sacral intumescence located between segments $\mathrm{T} 6$ and Ca1. This pattern is characteristic of the species and differs from that found in birds and mammals.

\section{REFERENCES}

Anthony J. 1970. Le névraxe des reptiles, p.202-213. In: Grassé P.P. (Ed.), Traité de Zoologie: anatomie, systématique, biologie. Reptiles caractères généraux et anatomie. $2^{\text {ième }}$ ed. Masson et Cie Editeurs, Paris.

Baumel J.J. 1993. Handbook of Avian Anatomy. Nuttall Orthological Club, Cambridge. 779p.

Carvalho R.C., Sousa A.L., Moura C.E.B., Faria T.N., Costa W.P., Resende H.R.A., Pereira H.M. \& Mariana A.N.B. 2003. Morfologia do pênis do jabuti das patas vermelhas (Geochelone carbonaria Spix, 1824). Revta Bras. Reprod. Anim. 27(2):229-230.

Castaño-Moura O.V. 1985. Notas adicionales sobre la reproducción y el crescimento de los mocorrocoyes (Geochelone carbonaria y G. denticula$t a$, Testudines, Testudinidae). Lozania 52:1-5.

De Lahunta A. 1983. Veterinary Neuroanatomy and Clinical Neurology. $2^{\text {nd }}$ ed. W.B. Saunders, Philadelphia, p.169-220.

Dellmann H.D. \& Macclure R.C. 1986. Sistema nervoso central, p. 186-190. In: Getty R., Rosenbaum C.E., Ghoshal N.G. \& Hillmann D. (Eds), Sisson/ Grossman Anatomia dos Animais Domésticos. 5a ed. Guanabara Koogan, Rio de Janeiro.

Faria T.N. 2000. Distribuição da origem, trajeto e número das principais artérias do jabuti Geochelone carbonaria (Spix, 1824). PhD Dissertação, Universidade de São Paulo, São Paulo, p.1-8.

Fontenelle J.H., Nascimento C.C., Cruz M.L., Luna S.P.L. \& Nunes A.L.V.N. 2000. Anestesia epidural em jabuti piranga (Geochelone carbonaria).
Anais 4ํㅡㄹ Encontro da Associação Brasileira de Veterinários de Animais Selvagens, 9o Encontro da Associação Brasileira de Animais Selvagens, São Pedro, SP, p.7.

Ghoshal N.G. 1986. Nervos espinhais, p.620-642, 1052-1077, 1294-1307, 1595-1617. In: Getty R., Rosenbaum C.E., Ghoshal N.G. \& Hillmann D. (Eds), Sisson/Grossman Anatomia dos Animais Domésticos. 5a ed. Guanabara Koogan, Rio de Janeiro.

Gil V.A. 1998. Neurología en Perro y el Gato. Marban, Madrid, p.17-24.

Guibé J. 1970. Le squelette du tronc et des membres, p.33-48. In: Grassé P.P. (Ed.), Traité de Zoologie, anatomie, systématique, biologie: Reptiles caractères généraux et anatomie. $2^{\text {iéme }}$ ed. Masson et Cie Editeurs, Paris.

Hildebrand M. 1995. Sistema nervoso: geral, medula espinal e nervos periféricos, p.331-347. In: Hildebrand M. (Ed.), Análise da Estrutura dos Vertebrados. Ateneu, São Paulo.

Kuhlenbeck H. 1975. The central nervous system of vertebrates. SK, Switzerland, p.150-161.

Mader D.R. 1996. Euthanasia and necropsy, p.241-247. In: Mader D.R. (Ed.), Reptile Medicine and Surgery. W.B. Saunders, Philadelphia.

Medem F., Castaño O.V. \& Rugeles M.L. 1979. Contribuición el connocimento sobre la reproduccion y el crescimento de los mocorrocoyes: $\mathrm{Ge}$ ochelone carbonaria y $G$. denticulata, Testudines, Testudinidae. Caldasia 12(59):497-511.

Messonier S.P. 1996. Common reptile diseases and tratament. Blackwell Science, Texas, p.1-3, 103-128.

Molenaar G.J. 1997. 0 sistema nervoso, p.175-224. In: Dyce K.M., Sack W.O. \& Wensing C.J.G. (Eds), Tratado de Anatomia Veterinária. 2ª ed. Guanabara Koogan, Rio de Janeiro.

Poug F.H. 1997. Herpetology. Prentice Hall, New Jersey. 75p.

Pritchard P.C.H. 1979. Encyclopedia of Turtles. TFH Publications, New Jersey, p.326-330.

Romer A.S. 1997. Osteology of the Reptiles. University of Chigago Press, Chicago. p.218-275.

Romero S.M.B. 2000. Fundamentos de neurologia comparada: da recepção à integração. Holos, Ribeirão Preto, p.131-135.

Silva D.R., Amorim-Junior A.A., Amorim M.J.A.A.L., Andrade M.B., Araújo F.P. \& Pimentel P.D. 2002. Topografia do cone medular da preguiça (Choloepus hoffmanni Peters, 1865 e Bradypus variegatus Shinz, 1825). Anais 20 o Congresso Brasileiro de Anatomia, Alagoas, Maceió, p.95.

Troiano J.C. 1991. Manejo Sanitario de Reptiles en Cativeiro. Prensa Veterinaria Argentina, Buenos Aires, p.75-117.

Vanzoline P.E. 1999. A note on the reproduction of Geochelone carbonaria and G. dendiculata (Testudines, Testudinidae). Revta Bras. Biol. 59(4):593-608.

Villa J.D. 1994. Presence of the tortoise Geochelone carbonaria (Reptilia: Testudines) in the Corn Islands, Caribbean Nicaragua. Revta Biol. Trop. 41(3B):924-928 